\title{
Humanistic trend in education in a global context
}

\author{
Olga Tolstova ${ }^{1, *}$, and Yuliya Levasheva ${ }^{1}$ \\ ${ }^{1}$ Department of "Pedagogy, Philosophy and History", Samara State Agrarian University, 2 Uchebnaya str., 446442, settlement Ust- \\ Kinelsky, Russia
}

\begin{abstract}
The purpose of the research is to study the peculiarities of the realization of the humanistic trend in education in the conditions of electronic informational and educational environment. A comparative approach is used in the research. This approach allowed the author to establish that one of the trends of the development of educational systems of Russia, China and the United States is a humanistic trend in education, which has its own national characteristics and peculiarities associated with the traditions, customs and particularity the development of national educational systems in these countries. The author reveals the general vector of development of the humanistic trend in education in Russia, China and the USA in the conditions of the electronic informational and educational environment, manifested in the following features. They are 1) equality in education for students; 2) the creation of a common scientific and educational space; 3 ) a teacher or a professor departs from the directive role, he plays the role of a facilitator and a consultant; 4) the students play the active roles, they interact freely with each other in an online environment (the principle of interactivity). Besides, 5) the students are responsible for the results of the independent learning activities, motivated for the process of the independent knowledge acquisition; 6) the students learn to master the "Lifelong Learning" principles. In addition, 7) the students master the competencies of the digital economy and education, learn to build human relationships, to show empathy, learn to form value attitudes towards society and life.
\end{abstract}

\section{Introduction}

Trends of the formation of a common educational space are due to the development of science. The important vector of the development of education in different countries is the humanistic trend, contributing to the formation of the personality, the formation of a value attitude to the world.

The Russian scientists have achieved certain results in analysing the problems of the development of education in foreign countries, including the United States and China. It is very important to study the educational experience of these countries. In particular, the educational system of China led the country to the leading position in the world and the second place in the economy after the USA. The pedagogical experience gained in these countries attracts the attention of the scientists from different countries. An important problem of education is the formation of the value humanistic relations of students to the world in the era of information technologies, which determined the relevance of our research.

The realization of the paradigm of the humanization of education in the modern electronic informational and educational learning environment is of particular importance, which determined the problem of our research, the realization of the humanistic trend in education in modern conditions.
The aim of our research is to study the features of the implementation of the humanistic trend in education in the conditions of electronic informational and educational environment.

The methodological basis of the research is axiological-humanistic theories of personality; scientific pedagogical theories that implement the humanistic trend in education. A comparative approach allowed the author to identify the general vector of the development of the world educational systems. The research methods are the analysis of domestic and foreign scientific literature on the problems of humanization of education; comparative research methods; sociological research methods: survey, interviews; pedagogical observation.

\section{Discussion and Results}

Humanism (from the Latin word "humanus" - humane, "homo" - man) - worldview, in the center of which is the idea of man as the highest value [1].

Man is looking for himself in this world, looking for immortality, the meaning of his life. Within the framework of humanistic pedagogy, a school is considered as a spiritual ladder, a ladder of the ascent of the soul, a spirituality of a growing person. A teacher is a carrier of spirituality, culture, tastes, love, knowledge, wisdom, which he passes to the students [2].

\footnotetext{
* Corresponding author: stommm3@mail.ru
} 
The humanistic trend in education involves the formation of «human» values of students, the teacher's ability to understand the students, the attention of the teacher to the feelings and emotions of students, the involvement of students in the process of acquiring knowledge.

In the conditions of digital education, the realization of the humanistic trend in education arises most acutely. These are issues related to the formation of the student's personality in conditions of modern electronic educational environment, not only with a positive, but also with a negative impact of the electronic environment on the student's personality, issues related to the qualities of the person that need to be formed in students in the conditions of digital education.

The humanistic trend in education involves, firstly, students 'mutual aid, co-creation between themselves and with the teacher, the formation of students' so-called "soft skills", that is, the formation of skills to build human relationships, the ability to engage in a dialogue, interact, work in a team and create collective projects "images of the future" and the development of creative abilities. Secondly, the humanistic trend in education contributes to the formation of students' universal competences, such as, teamwork and leadership, communication, intercultural interaction, selforganization and self-development [3], implies the creation of conditions for the active role of the students taking into account their interests. The personality of the student is placed in the centre of the teaching process [4].

Modern electronic informational and educational environment provides students with the opportunity to show their activity at online classes and at the virtual exhibitions. A virtual exhibition is provided on the university website. Abstracts, scientific articles, projects, technical creativity, etc. are presented on the exhibition. And this process is permanent [5].

The general trend of modernization of the world education systems is the active use of information and communication technologies, in particular, the use of information and communication technologies (ICT) for equal quality education and lifelong learning; ICT contribution to knowledge creation and dissemination [6]. The students will have to learn, in accordance with the modern standard of universal competence UK-6, rationally manage their time and, most importantly, build and implement the trajectory of their own development [3], and for this they must know and own the principles of lifelong learning. The slogan of modern education: "Lifelong Learning".

In the context of the electronic informational and educational environment, it is important not to miss the human dimension, not to lose the student's identity in the flow of information and modern technologies. A modern student must possess such competencies that allow him to work in the digital informational and educational space and at the same time remain a "person", he should have a value attitude to the world and to a person: a person is the goal and measure of all of things.

A modern specialist should possess competencies of the digital economy, including professional activities.
And the centralization of the pedagogical process on the personality of the student contributes to the cooperation of the students among themselves, the rallying of the teacher and the students. But digitalization is necessary only as a tool.

It is planned to equip all schools of the Russian Federation with high-speed Internet, the speed of which will be 50-100 megabits per second. Internet speed will be increased 400 times. This kind of electronic informational and educational environment will cause changes in education itself.

Students can form virtual groups and create online projects together with students from other regions of the Russian Federation and students from foreign countries. They can take part in online contests and quizzes.

In the Russian Federation 100\% of urban schools and $99.2 \%$ of rural schools are currently equipped with the Internet. A digital school is a school of the future. It will be created on the basis of one of the rural schools and will be equipped with an electronic security system. A well-trained specialist, not a teacher, will quickly and professionally enter all data into an electronic journal at this school. The administrative building of this school will be digitized. The electronic boards will be in the classes. A regular board will be placed on the top of the electronic boards, and together they will form a single complex in the classes.

It is necessary to pay attention to the fact that modern electronic information and communication technologies are only the means that supply educational material, tasks, and students, which allow monitoring of students' educational achievements, and they do not significantly affect the results of students' educational achievements. The number of computers does not affect the quality of education. It is proved that a student who works at a computer no more than twice a week shows the results of training, higher than that of a student who works at a computer every day.

The designer of the Moscow E-School is used to create the Russian E-School (RESH) - a platform for the teachers and the parents. The Presidential Decree "About the national goals and strategic objectives of the development of the Russian Federation for the period up to 2024" states that the main goal of Russian education is the global competitiveness. The educational system of the Russian Federation should enter the next six years in the top ten countries with the best general educational system. Special attention is paid to the upbringing of a person: "upbringing of a harmoniously developed and a socially responsible person on the basis of the spiritual and moral values of the peoples of the Russian Federation, on the basis of historical, national and cultural traditions" [8].

This goal fully contributes to the realization of the humanistic trend in education, which involves the formation of a comprehensive (the intellectual, moral and physical development) and harmoniously developed personality of the student, taking into account her abilities and inclinations, as well as taking into account the value attitudes formed in her. The intellectual, moral and physical development must be in harmony. 
The Presidential Decree pays attention to the creation of a "modern and safe digital educational environment that ensures the high quality and accessibility of education of all types and levels" [8].

The flexibility and accessibility of education of all types and levels allows us to provide a digital educational environment, thus realizing one of the principles of the humanistic trend in education.

The humanistic paradigm of education smoothly passes into the electronic informational and educational space, providing students, who are in different regions of the country, with equality in education.

Three projects are realized in China: "distance class", "elite teacher class" and "elite cyber school", which expand the use of ICT in education. The realization of these projects will make the educational opportunities for students in rural and urban schools the same [9] (the humanistic trend in education).

The goal of these projects is to exchange the highquality digital teaching materials in schools, to improve the quality of education and the educational opportunities of students.

The project "elite teacher class" assumes that the best teachers are invited to conduct cyber classes for students located in remote areas.

"Elite cyber school" provides high-quality digital learning resources with the help of cyber classes to reach as many students as possible.

Through the "distance class" project, schools in remote rural areas can access classes provided by schools in urban areas with the rich digital educational resources.

At the same time, the digital technologies should be aimed at improving the quality of education. The problem of the quality of education goes beyond the traditional concept of educational achievements and involves the formation of knowledge and skills that can meet the requirements of the information age [10].

It is necessary to form not only students' knowledge, but also to develop their ability to process information, to develop the ability to cooperate and to learn in the age of information and communication technologies.

R. K. Wagner formulated seven basic skills, abilities and qualities that a person needs to survive in the information age: 1) the ability to think critically and solve problems, 2) the ability to collaborate and the presence of leadership qualities, 3) flexibility and ability to adapt to constantly changing conditions, 4) initiative and enterprise, 5) the ability to communicate effectively in oral and written forms, 6) the ability to find and analyze information, 7) curiosity and imagination [11].

ICT integration methods are being studied and implemented in curricula in China to improve the quality of education. The "student- centred and teacher-guided" model was created by the Chinese scientists in accordance with the conditions of education in China [12].

Various models of ICT infusion into the educational process were created under the guidance of scientists with the aim of improving the quality of education within the framework of this model.
At the same time, the humanistic pedagogical paradigm implies not only the choice of students, but also the formation of students' skills to be responsible for their choices. The students not only make choices, for example, they choose the training modules, but they are also responsible for the learning outcomes.

The ideas of humanistic psychology and pedagogy were substantiated in the works of the American scientists such as C. Rogers, A. Maslow, A. Combs. The theory of self-actualization, which was developed by A. Maslow, describes the needs of the individual, which cause him to seek higher achievements. A. Maslow builds the needs in a pyramid, which is called "a hierarchy of needs". Self-actualization is a state of attaining the highest point of opportunity, the full realization of potential $[13,14]$.

A process, in which the student himself discovers and independently learns knowledge, influences the behaviour of the student, according to C. Rogers. In his opinion, the task of the teacher is to direct the intellect of the student to the development of personality in order to help him learn about the world around him [15] and build value relationships with this world.

Mark Prensky introduced the term "digital natives", by which he meant a generation of young people who were committed to a new education. The term is used to describe students who were born in the digital world and for whom all forms of information and communication technologies are natural. The older generation, which was born earlier, is "digital immigrants" who hardly keeps up with the natives, the scientist believes. Using the term "digital natives", he mentioned a group of young people who are immersed in technology throughout their lives. "Digital natives" is a generation of young people who possess complex technical skills and have educational preferences for which the traditional education is not prepared [16].

Students use a variety of technologies to communicate with their friends and interact with the outside world, but they use them primarily for personal purposes and entertainment. At the same time, students are well acquainted with the basic skills of working with Microsoft Office (Word, Excel, PowerPoint), sending emails, text messages, using Facebook, and surfing the Internet [17].

The concept of "digital natives" has gained some popularity. Additional features have been added to it. Erika E. Smith from the University of Alberta offers eight characteristics of digital natives.

Erika E. Smith describes digital natives as follows: they have new ways of knowing the world; they are the drivers of the digital revolution and thus they change society, they have technological literacy; they are able to solve several tasks simultaneously, they are focused on teamwork and cooperation. Besides, they are native speakers of technology and they have unique points of view on solving different problems; they have a good command of gaming, interactive technologies and modeling technology; they require immediate satisfaction of their needs; they reflect the economy of knowledge and react to it [18]. 
Therefore, the teacher is faced with the task of realization of a humanistic trend in education in the electronic informational and educational space.

The realization of a humanistic trend in education requires overcoming the emotional barriers to communication when using technology. Modern students, who are accustomed to the constant and daily use of technology, consider entering into a real dialogue with other people too risky for themselves. Technology changes the process of thinking and communication. A dialogue in the digital age is reduced to the controlled transactions. Asynchronous messages are not the genuine interaction necessary for a person. They make the communicants, the participants of a dialogue, simply meet certain requirements set forth by the instructor. Computer monitors contribute to passivity, "broken" attention and a sense of social isolation of students.

The proponents of critical pedagogy, which opposes the technocratic foundations in teaching, believe that teaching will take place, if there is anyone to teach, and the interaction of the teacher and the student, the dialogue between them can contribute to the building human relations, the humanization of human relations. Critical pedagogy takes into account the cultural and educational environment and considers the interaction, the true «live» dialogues of students among themselves and with the teacher. The more technologies penetrate the life of a modern person, including the educational system, the more natural component of human life in the modern world they become. Technologies are often associated with concepts of "progress" and "innovation".

From the point of view of critical pedagogy, the main goal of modern education is not to prepare a student for life in a world that already exists, but to prepare a student for life in the future world, to represent this world together with students. Tomorrow students will build and create this world themselves.

The modern world is digital. But at the same time, the question arises about the consequences of the constant impact of technology on the student. Critical pedagogy believes that technology has a dehumanizing effect on the teaching process. Critical pedagogy raises the following questions: "How all technologies are actually useful for a person's life?", "Are they really necessary for a person to live?", "Will the school turn into "an innovative" incubation platform without taking into account the influence and consequences of constant impact technologies on students" [19].

In the Russian Federation, at the Samara State Agrarian University, a survey of students of technological, economic, engineering faculties and the faculty of biotechnology and veterinary medicine was conducted in order to identify the attitude of students to modern electronic information and communication technologies and to the organization of the teaching process in an electronic informational educational environment. One hundred respondents took part in the survey.

To the question, "Would you like a lesson to be held in a traditional form or using modern information and communication technologies?" $100 \%$ of respondents answered that they would like modern information and communication technologies to be used in classes. At the same time, $97 \%$ of respondents indicated that they did not want the teaching process to be completely transferred to the distance form and only the e-learning was used. There is a reason for this choice, $96 \%$ of respondents preferred the real interaction between the professor and the students, "human interaction"; $3 \%$ of students have to combine study and work and they believe that distance education would help them a lot.

To the question: "What professional and personal qualities do you most value in a professor?" $96 \%$ of students preferred the professor's professionalism. Respondents put the professionalism of the professor in the first place; $93 \%$ of respondents want to see a creative professor, $80 \%$ of students answered that they like professors who are passionate about the subject they teach; $98 \%$ of respondents answered that they like professors who show empathy and $97 \%$ respondents like friendly professors.

Thus, in the conditions of the digital world and education, students put on the first place "the human dimension", "the personal qualities of professors". The research also found that students learn information more easily if they are sure that this information will not be available on the Internet. The students better remember where to find information on the Internet than they remember the information itself.

\section{Conclusion}

Thus, the humanistic trend in education in the conditions of digital education smoothly passed into the electronic informational and educational environment. In turn, this environment creates certain conditions for development of the humanistic trend in education. The realization of the humanistic trend in education in the conditions of the electronic informational and educational environment has its own characteristics. First, the electronic informational and educational environment provides equality in education for students located in different regions of the country. This issue is particularly relevant for countries with a large territory such as the Russian Federation, China and the United States. Second, the electronic informational and educational environment creates the conditions for creating a common educational and scientific space. The students from different countries can work on joint online projects, take part in international online competitions and quizzes. The scientists from different countries can jointly conduct research, share knowledge. Third, the humanistic trend in education assumes that a teacher or a professor departs from the directive role, he acts as a facilitator, guiding the learning process, a consultant, a neutral observer in certain pedagogical conditions. Fourth, the students play the active roles. They can interact with each other in the process of acquiring knowledge, form virtual learning groups. Moreover, such interaction contributes to the formation of their skills to build human relationships, engage in a dialogue, work in a team, and develop creative abilities. Fifth, the students can independently select and combine the learning 
modules. In such learning, they take responsibility for the process and the result knowledge acquisition. The humanistic trend in education implies that students are motivated to learn, to the process of acquiring knowledge. They know why they need knowledge, where and how they will use them, and the electronic informational and educational environment represents such opportunities. Sixth, using the electronic informational and educational environment, the student learns to manage their time rationally, to organize the process of acquiring knowledge and master the principles of education "lifelong learning". Seventh, a modern student should possess the competencies of the digital economy and education, but at the same time, in the conditions of digitalization, one should not lose the "human dimension", be able to enter into a dialogue, to communicate, to show empathy; a student should have formed a valuable attitude to "life" and "society". The humanistic trend in education is represented in the Russian Federation, China, the USA and other countries, and the electronic informational and educational environment allows us to consider this trend in a global context.

\section{References}

1. Humanism: concept, history, modernity, Retrieved from: http://filosofedu.ru/index.php/filosofijashpargalki-s-otvetami/809-gumanizm-ponjatieistorija-sovremennost

2. The Line of Life (2018). Retrieved from: https://www.youtube.com/watch?v=dTqmY3SnxlE

3. Federal State Educational Standard of Higher Education - Bachelor's degree in training 44.03.04 Vocational training (by branches of training Retrieved from: http://fgosvo.ru/uploadfiles/fgosvob/440304.pdf

4. L.A. Abramova, The development of science and education, Ch. ed. - Cheboksary: Publishing House "Sreda", 165-176 (2019). ISBN 978-5-6042304-7-3. doi::10.31483/r-22034

5. O. V. Kirillova, T. V. Kirillova, L. A. Abramova, I. V. Gavrilova, M. I. Vaibert, Eur. J. of Contem. Educ. Psychological and Pedagogical Support of the Formation of Professional World Outlook of the University Students, 6 (2), 280-288, (2017) DOI: 10.13187/ejced.2017.2.280

6. O.S. Tolstova, Pedagog. Zh. [Pedagog. J.], Modernizatsiya mirovykh sistem obrazovaniya na osnove informatsionno-kommunikatsionnykh tekhnologii [Modernization of the World's Educational Systems on the Basis of the Information and Communication Technologies]. 8 (6A), 71-78, (2018)

7. All-Russian Parents Meeting 2018]. (2018). Retrieved from: https://youtu.be/8z8dYedFnz8
8. Decree of the President of the Russian Federation "On the national goals and strategic objectives of the development of the Russian Federation for the period up to 2024". Retrieved from: http://kremlin.ru/events/president/news/57425 (2018)

9. Zhang J., Yang J., Fan L., Huang R. Innovation Scale-Up of ICT in Education in China. In: Looi CK., Teh L. (eds) Scaling Educational Innovations. Education Innovation Series. Springer, Singapore, (2015). Doi https://doi.org/10.1007/978-981-287537-2_9

10. Mu, G. M., Zheng, X., Jia, N., Li, X., Wang, S., Chen, Y., He, Y., May, L., Carter, M., Dooley, K., Berwick, A., Sobyra, A., \& Diezmann, C. Revisiting educational equity and quality in China through confucianism, policy, research, and practice. The Australian Educational Researcher, 40(3), 373-389. (2013). doi: 10.1007/s13384-013-01130.CrossRefGoogle Scholar

11. Wagner, R. K. Learning to read: The importance of assessing phonological decoding skills and sight word knowledge. New York: Scholastic Inc. (2008) Google Scholar

12. $\mathrm{Yu}, \mathrm{S}$. Looking for the informatization for China. Distance Education in China, 20, 39-41. (2004). Google Scholar

13. Abraham Maslow Encyclopædia Britannica. Retrieved from https://www.britannica.com/biography/Abraham-HMaslow. (2016).

14. Joaquín Selva, Abraham Maslow, His Theory \& Contribution to Psychology Retrieved from https://positivepsychologyprogram.com/abrahammaslow/ (2019).

15. McLeod, S. A. Carl Rogers. (2014, Feb 05). Retrieved from https:/www.simplypsychology.org/carl-rogers.html

16. Prentsky, Marc. "Digital Natives, Digital Immigrants." On the Horizon 9, 5 1-6. (October 2001):

17. P. De Bruyckere, P. A. Kirschner, C. D. Hulshof, American Educator, Technology in Education: What Teachers Should Know, 12-18 (Spring 2016). Retrieved from https://files.eric.ed.gov/fulltext/EJ1094203.pdf

18. Erika E. Smith, Canadian Journal of Learning and Technology, The Digital Native Debate in Higher Education: A Comparative Analysis of Recent Literature, 38, 3 (2012).

19. A. Morgan, Humanization in the Digital Age: A Critique of Technophilia in Education, Dissertation, Georgia State University (2018). Retrieved from https://scholarworks.gsu.edu/eps_diss/183 